\title{
Integrated NIR-HE based SPOT-5 image enhancement method for features preservation and edge detection
}

\author{
Farizuwana Akma Zulkifle', Rohayanti Hassan², Mohammad Nazir Ahmad ${ }^{3}$, Shahreen Kasim \\ Tole Sutikno ${ }^{5}$, Shahliza Abd Halim 6 \\ ${ }^{1}$ Fakulti Sains Komputer dan Matematik, Universiti Teknologi MARA, Kuala Pilah, Malaysia \\ ${ }^{1,2,6}$ School of Computing, Faculty of Engineering, Universiti Teknologi Malaysia, Johor Bahru, Malaysia \\ ${ }^{3}$ Institute of Visual Informatics, Universiti Kebangsaan Malaysia, Bangi, Malaysia \\ ${ }^{4}$ Faculty of Computing Science and Information Technology, Universiti Tun Hussein Onn Malaysia, Parit Raja, Malaysia \\ ${ }^{5}$ Department of Electrical Engineering, Faculty of Industrial Technology, Universitas Ahmad Dahlan, Yogyakarta, \\ Indonesia
}

\begin{abstract}
Article Info
Article history:

Received Jul 17, 2021

Revised Oct 6, 2021

Accepted Oct 23, 2021

\section{Keywords:}

Filtering method Histogram equalisation Image enhancement Shoreline detection SPOT-5 image

ABSTRACT

Recently, many researchers have directed their attention to methods of predicting shorelines by the use of multispectral images. Thus, a simple and optimised method using image enhancements is proposed to improve the low contrast of the Satellite pour l'Observation de la Terre-5 (SPOT-5) images in the detection of shorelines. The near-infrared (NIR) channel is important in this study to ensure the contrast of the vegetated area and sea classification, due to the high reflectance of leaves in the near infrared wavelength region. This study used five scenes of interest to show the different results in shoreline detection. The results demonstrated that the proposed method performed in an enhanced manner as compared to current methods when dealing with the low contrast ratio of SPOT-5 images. As a result, by utilising the near-infrared histogram equalization (NIR-HE), the contrast of all datasets was efficiently restored, producing a higher efficiency in edge detection, and achieving higher overall accuracy. The improved filtering method showed significantly better shoreline detection results than the other filter methods. It was concluded that this method would be useful for detecting and monitoring the shoreline edge in Tanjung Piai.
\end{abstract}

This is an open access article under the CC BY-SA license.

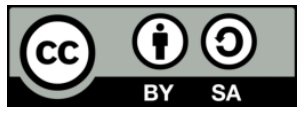

\section{Corresponding Author:}

Farizuwana Akma Zulkifle

Fakulti Sains Komputer dan Matematik, Universiti Teknologi MARA

Cawangan Negeri Sembilan Kampus Kuala Pilah, Kuala Pilah, Negeri Sembilan, Malaysia

Email: farizuwana@uitm.edu.my

\section{INTRODUCTION}

Shoreline delineation is difficult, time-consuming, and sometimes impossible for the entire coastal system when using traditional ground surveying techniques [1]-[5]. Consequently, in satellite images, there is a need to overcome the difficulties in the extraction of shorelines [3]-[21]. Many computational methods are yet to be improved, and comprehensive methodologies are needed to be developed to extract the complex properties of multi-features in satellite images [2], [6], [22]-[34]. The challenges of shoreline detection are faced during the extraction of dense area features, when the satellite images suffer from surface reflectance during data acquisition [2], [4], [5], [22], [31], [32], [35], [36]. The current methods are discussed to analyse the limitations that occur during shoreline detection. There are several objectives explained, which indicate as to why this research is being conducted to notify the importance of accomplishing the goal. Furthermore, Satellite pour l'Observation de la Terre-5 (SPOT-5) images are used throughout this study by utilizing the 
pan-sharpened image with a combination of the false color composites which consist of near-infrared (NIR), red, and green channels. Subsequently, the contrasts of the SPOT-5 images are improved by integrating the near infrared histogram equalization (NIR-HE) method for features preservation and edge detection [23], [33], [37]-[40].

An image captured in bad weather often yields low contrast results, due to persistent cloud cover and haziness, which attenuates scene radiance [23], [41]. Hence, electromagnetic energy is unable to reach the sensor before it passes through a substantial atmospheric scene [23], [42]. Hazy days in Malaysia are most likely to occur from January to February and from June to August [43], [44]. Haze is the appearance of atmospheric absorption and scattering of gases. The particles that cause the hazy appearance may originate from many sources, some of which are natural sources and some of which are anthropogenic sources [45]-[47]. Natural sources include the oceans, forests and the ground surface. However, a majority of the particulates originate from human activities such as open burning, land clearing and the combustion of fossil fuels in industrial boilers. Images taken with surface reflectance conditions will be affected by the low contrast [42]. Therefore, misclassification of features may occur due to low contrast. The efficiency of the haze removal method to remove haze is probably not quite as sufficient as the multispectral data applied, which is meant for retrieving features in the incorrect classes.

Moreover, imagery with the presence of surface reflectance is prone to have weak edges, poor visibility, and misclassified pixels [46]-[50]. As a result, this would produce inefficient extraction of multiclasses, which causes missing line cues and a mixture of features. In order to produce a prediction of shoreline changes, the second challenge is to cater, which is to improve the filtering method by sharpening the image boundaries and eliminating the problem of misclassified pixels of the shoreline. Unfortunately, the prediction of shorelines is often poor because of inaccurate features due to misclassification. The images may lose image information [51]. As a consequence, an improved filtering method is essential for drawing more reliable edges for shorelines, with a high accuracy of features classification. These would eventually produce clear recognition and extraction of shorelines [2], [4], [22], [32], [35]. Additionally, for each application and image, a custom image enhancement method, and an adjustment of contrast while preserving the edges are usually necessary.

The goal of NIR-HE using the NIR channel is to improve the image contrast and hence to make it suitable for classification of vegetation in feature extraction [2], [28], [33], [38], [40], [48], [52]-[55]. The false color composite image is enhanced using HE algorithm. The range of brightness values presented in an image is referred to as a contrast. Thus, the contrast is enhanced efficiently by using HE in a SPOT-5 image. An advantage of this method is that it manipulates the NIR channel, green channel and red channel [56]-[67]. By utilizing the NIR channel, it is important to note that the deep penetration of its long wavelength makes it possible to unveil the details of vegetation that could otherwise be lost entirely [49], [53], [62], [68]-[70]. The purpose of the NIR-HE method is to improve the low contrast of an image caused by surface reflectance issues. This paper is composed of several sections. Section 2 discusses research method on image enhancement, pan-sharpening, integrating NIR channel and image classification. Section 3 explains the analysis of the image enhancement method and analysis of feature signatures. The conclusions and recommendations for future work are presented in section 4.

\section{RESEARCH METHOD}

\subsection{Image enhancement}

Many researchers in recent years have focused on images taken in bad weather, which often produce low contrast results due to the presence of surface reflectance in the atmosphere, which reduces scene radiance [71]. In the process of image enhancement, the noise will be removed from the images, and the image contrast will be enhanced. Low contrast images with weak edges pose challenges in the fields of computer vision and pattern recognition [72]. However, the all year round tropical hot and humid climate in Malaysia is also a challenging problem because of the relevance between the persistent cloud covers and hazy days. Removing the noises can increase the visibility of the scene, correcting the color shift affected by the air light [73].

Images with surface reflectance conditions will reduce visibility, and low contrast images reduce the performance of various image processing and computer vision techniques [41]. The dehazing method is a standard technique to remove surface reflectance and ensure high image visibility, as well as to correct the color shift caused by the air light [74]. The image with the presence of surface reflectance issues is prone to have biased low contrast scene radiance. However, haze removal has been a challenging issue where the hazy situation is dependent on unknown depth information [74]. According to [75], the original details of images need to be preserved, even though the visuality of an image has been improved. Many approaches have been proposed for addressing the problem of surface reflectance condition such as hazy and cloudy conditions. 
These approaches are categorized into two types: multiple image processing or additional information methods [76]-[79], and single image processing approaches [29], [42], [43], [73], [80]-[82]. Therefore, a comprehensive study to improve the surface reflectance problem while maintaining detailed information on an image is highly recommended.

\subsection{Pan-sharpening of SPOT-5 images}

As depicted in Figure 1, pan-sharpening was used to increase the spatial resolution, and to provide better visualization of a multiband image, using a lower-resolution and single-band image [83]-[86]. Pansharpening is the process of merging multispectral and panchromatic imagery, thereby creating a single highresolution colour image. A panchromatic image contains only one wide channel of reflectance data. Modern multispectral scanners also generally include some radiation at slightly longer wavelengths than red light, called near infrared. Panchromatic images can be generally collected with a higher spatial resolution than a multispectral image, because the broad spectral range allows for smaller detectors to be used while maintaining a high signal-to-noise ratio [7], [84], [87], [88]. In contrast, a multispectral image is one that contains more than one spectral channel. A simple example of a multispectral image is a colour image which contains three channels, corresponding to the red, green and blue wavelength channels of the electromagnetic spectrum [89]-[105].

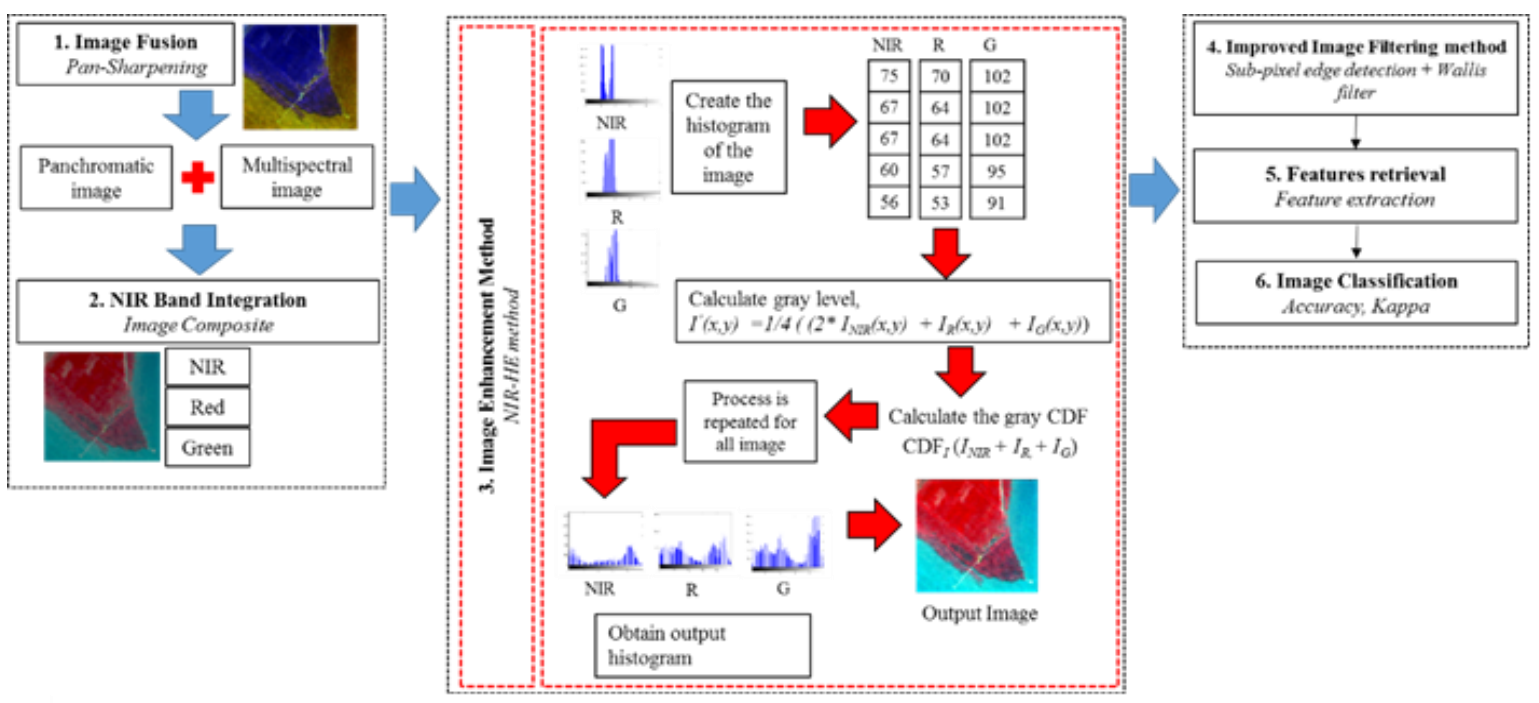

Figure 1. Proposed method

\subsection{Integrating near-infrared channels}

After the process, a multiband raster dataset $(R, G, B)$ is produced. Then, the data image can choose either a single channel of data or can form a colour composite from multiple channels [84]. A combination of any three available channels within a dataset can create red, green, and blue (RGB) composites [106]-[113]. There are many possible schemes for producing an RGB composite or false colour composite images. However, each scheme has the ability to detect specific objects in an image. In this study, the false colour composites include the NIR channel, the green channel $(G)$ and the red channel (R), as depicted in Figure 2. This integration of NIR channels is suitable for detecting vegetation and water bodies. There is a combination of the false colour composite used in detecting vegetation, with the red channel replaced in the NIR channel. The use of the NIR channel can help find a suitable local patch for air light-colour estimation [51].

Figure 2 shows a comparison of the histogram between an RGB image and false colour images. The histogram shows that the curve for an RGB image is within the range of 89 and 122, while the false colour image lies in the range between 25 and 200. This indicates that a pixel does not span a full range of RGB images. Moreover, the peak signal-to noise ratio (PSNR) value for the false colour image is shown to be slightly higher than that of the RGB image, due to the NIR channel's integration onto the image [114]-[117].

This encourages the use of a false colour image throughout the study and the presence of an NIR channel, which makes the vegetation more vibrant and helps with edge detection and feature extraction [118]. Although the NIR channel helps improve vegetation and water body detection, the image needs to undergo image enhancements, in order to improve its image contrast and to improve its extracted edge detection. 


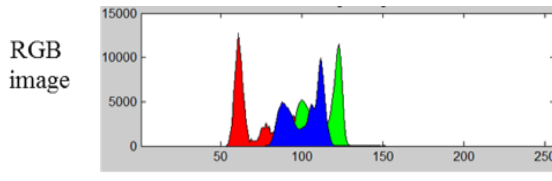

(a)

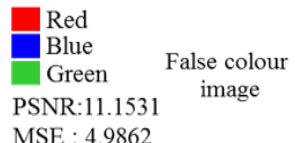

MSE : 4.9862

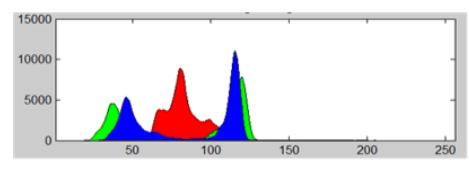

(b)

Figure 2. Comparison histogram between (a) RGB image and (b) false colour

An image contains one or more colour channels, which defines the pixel location. The conversion of images is achieved through a colour map. The most common colour map is grayscale, which involves all shades of grey from black to white. Therefore, grayscale is particularly well suited to images with high intensity [119]-[122]. In addition to utilizing false colour, a map can better display the intensity in images [123]. Therefore, false colour images are mostly able to delineate and identify features for a human observer. An intensity scale known as the grayscale level, is in a digital image with an $\mathrm{m} \times \mathrm{n}$ array of values, for each pixel in a single sample, containing the image intensity information. In the 8 bits per sample pixel, up to 256 shades of gray are utilized.

The conversion of an RGB image to grayscale is a common approach used to retain information regarding brightness, and for discarding the values of hue and saturation. Each pixel is made up of three colours, including red, green and blue, which are used to describe intensity. In the RGB colour model, a colour image represents the intensity function presented in (1),

$$
I=\left(I_{R}, I_{G}, I_{B}\right)
$$

where $I_{R}$ represents the intensity value of the pixel in the red channel, $I_{G}$ represents the intensity value of the pixel in the green channel, and $\mathrm{I}_{\mathrm{B}}$ represents the intensity value of the pixel in the blue channel.

The intensity of each colour channel is usually stored through the use of eight bits. Therefore, multispectral images store multiple values for each pixel, captured through the amount of light in different channels of the electromagnetic spectrum. The common multispectral images are RGB, which contain three channels that correspond to the R, G and B regions of the spectrum [39], [60], [84], [88], [94]. However, throughout the study, the false colour image is used, where the three channels correspond to the NIR, R and $\mathrm{G}$ regions. Converting a false colour image to a grayscale image involves mapping a three-channel image $(\mathrm{m}=3)$ to a single channel image $(\mathrm{n}=1)$. Therefore, a simple approach is considered, which involves averaging the three channel values, as presented in (2):

$$
I=\left(I_{N I R}+I_{R}+{ }_{I G}\right) / 3
$$

where $\mathrm{I}_{\mathrm{NIR}}, \mathrm{I}_{\mathrm{R}}$ and $\mathrm{I}_{\mathrm{G}}$ are the NIR, red and green channels of the input image, respectively.

However, the resulting image is not equally sensitive to all frequencies. Therefore, the channel average is tested by increasing the weight of the NIR channel. A significant improvement has been proposed by modifying the weight of the NIR channel. As a result, the gray levels for each channel are calculated and implemented, through using (3),

$$
I^{\prime}=\left(\left(r * I_{N I R}\right)+I_{R}+I_{G}\right) / t
$$

where ' $r$ ' is the number of adding the NIR channel, 'NIR' is near-infrared, ' $G$ ' is green, ' $R$ ' is red, and ' $t$ ' is a channel's total number.

The gray levels for each colour channel are calculated and implemented. In regards to false colour values, NIR is $102, \mathrm{R}$ is 90 , and $\mathrm{G}$ is 75 . Then the image is tested to convert back to the false colour, through usage of a non-replicating transformation. This step ensures that the changes of the additional NIR channel serve to make the image darker or brighter, and also to ensure that the values are still within the range of 8-bit values. Therefore, the three separate colour channels are shown through settings, while the other colour channel is zero. For example, the NIR channel is visualized through (4).

$$
I_{N I R}=I_{N I R} ; I_{R}=0 ; I_{G}=0 ;
$$

Therefore, the grayscale image is formed through utilising values from the NIR channel as (5).

$$
I^{\prime}{ }_{N I R}=I_{N I R} ; I^{\prime}{ }_{R}=I_{N I R} ; I_{G}^{\prime}=I_{N I R} ;
$$


From the results shown above, the average approach tends to increase the contrast. The formula manipulates the NIR channel weight, where the channel reflects more than other channels, given that the human visual system is more sensitive to the NIR channel than to the other channels. The advantages are that the division by four implements, due to an average of three channels and the addition of one channel weight, through multiples of two, by the weight of the NIR channel. Therefore, it may increase the NIR channel's weight. However, if the average used is more than two channels of the NIR channel, then the images will show greater contrast, and will cause image information loss and mixed pixels. As a result, the proposed method is suitable for a low contrast image of SPOT-5, whereby multiplying by two into the weight of NIR, will make the channel reflect the vegetation in the area of Tanjung Piai. In this case, the plants reflect NIR and green light, and absorb red. Therefore, the channel reflects more NIR than green, whereby plant-covered land appears to be deep red [30].

\subsection{Image classification}

The image classification process must be performed to identify and compare the accuracy by support vector machine (SVM) [33], [124]-[154]. In this study, a few polygon samples were created for training classes. These comprised of four classes, namely: vegetation, developed area, sea, and soil. These four features are selected not only because they are useful for shoreline edge detection, but also because these are essential for most urban planning applications which include development of areas, shoreline and vegetation extraction. Throughout the SVM method, the radial basis function (RBF) [126], [130], [146], [154] for kernel type and the threshold value of 0.70 are used for the classification process. Several trial-and-error run values using a threshold value in between the range of 0.10 and 0.70 are chosen in the initial experiments. These parameters obtained a higher accuracy performance level with more than $78 \%$ accuracy for all datasets.

\section{RESULTS AND DISCUSSION}

\subsection{Analysis of the image enhancement method}

The intensity of the contrast enhancement method has been observed through the enhanced images [155]-[165]. By using NIR, the red-colored pixels are produced, and it is more obvious when representing the healthy vegetation area. NIR helps penetrate further than the visible channel, due to its long wavelength. In this case, a darker image is assumed to be unable to reflect any solar energy, which indicates the histogram of a nearly zero digital number or brightness value. If the image presents surface reflectance, then the histogram of the visible channel shows a sharp increase in occurrence frequency at the lowercontrast level. Therefore, the pixel intensity histogram's leftwards skew indicates that the image is considered to have a dark level, with a low brightness level; and if the pixel intensity histogram is skewed to the right, then the image is considered to have a higher brightness level. Moreover, for the contrast level, if the pixel intensity histogram focuses on the center of the histogram, then the image will have lower contrast. On the other hand, if the pixel intensity histogram is distributed throughout the histogram range, the image will have a higher contrast level. This indicator was used to assess the image enhancement methods, using a variety of illuminations for optimal performance [28], [85], [86], [105], [140], [166].

The HE method was used to apply image enhancement individually to the gray-level images [167]-[176]. The NIR channel was integrated into the false color composite, combining the red and green channels, instead of the red, blue and green channels. The fusion criteria were based on the observation of the NIR channel images, which have higher contrast. Therefore, the NIR channel was used to refine the image's contrast. The HE method enhances the image by distributing the image brightness levels equally across the brightness scale [1], [11], [15], [21], [44], [53], [54], [72], [94], [119], [136], [140], [145], [150], [159], [168], [169], [172], [175]. Furthermore, the intensity of the contrast enhancement method is measured through the root mean square (RMS), where the higher the RMS value, the better the contrast image [22], [35], [48], [178]-[181]. As depicted in Table 1, the image enhancement methods for SPOT-5 images have been compared and ran to produce the best approach. The results of the histogram of colour pixel intensity distribution were analyzed. At this point the four methods produced three coloured pixels, including healthy vegetation areas indicated by red pixels, water areas indicated by blue pixels, and non-vegetated/developed areas indicated by white pixels.

The RMS values for the initial image have shown the lowest values, when compared to other methods. For the dark channel prior (DCP) method, the RMS value of scene three was 0.2441 . Therefore, the image was not fully enhanced to its optimum level, after which it turned dark and the vegetation was harder to identify. The HE method performed an image contrast enhancement individually to the gray-level image. The HE method removed the surface reflectance in an image and enhanced the image contrast of the gray image. Therefore, the HE method produces better contrast, when compared to the DCP method, which produces an image with very high brightness, for all spectral channels. The HE method produced an RMS 
value which is nearly equal to the proposed method, specifically 0.4192 for scene one, 0.4478 for scene two, and 0.4612 for scene three. However, the decorrelation stretch (DECORR) results are more suitable for densitybased vegetation analysis, from which it is fit and able to distinguish more than one feature [182]- [194]. On the other hand, the proposed method enhanced the image by distributing its brightness levels together with the whole brightness scale [118], [193]. Therefore, the image has been improved to its optimum level, without losing details or causing shifts in colour. The RMS value for the proposed method shows the highest value, when compared to others. From this result, it can be concluded that the proposed method provides a higher image quality after image enhancement, and the image is surface reflectance-free.

Additionally, the peak signal-to-noise ratio (PSNR) is commonly used as a measure for image quality reconstruction. PSNR is the ratio between maximum possible power and corrupting noise which impacts an image's representation. On the contrary, the mean square error (MSE) represents the cumulative squared error between the enhanced image and the initial image. As a result, PSNR and MSE are interrelated. Where there is higher PSNR and lower MSE, a better contrast can be achieved [98], [171], [195]-[199]. Table 2 shows a comparison of PSNR and MSE results, when using the different methods. As seen in the Table 2, the proposed method has the highest PSNR when compared to the other methods. The use of the proposed method provides a greater contrast level, following the process of improving the low-contrast images. Therefore, the proposed method improves an image's contrast, when compared to other methods.

Table 1. Overall observation of RMS for Scene 1, Scene 2, Scene 3, Scene 4, and Scene 5

\begin{tabular}{|c|c|c|c|c|c|}
\hline Method & Scene 1 & Scene 2 & Scene 3 & Scene 4 & Scene 5 \\
\hline \multicolumn{6}{|c|}{ Initial Image } \\
\hline & RMS: 0.1328 & RMS: 0.1523 & RMS: 0.1645 & RMS: 0.1741 & RMS: 0.1923 \\
\hline \multicolumn{6}{|l|}{ DCP } \\
\hline \multicolumn{6}{|l|}{$\mathrm{HE}$} \\
\hline $\begin{array}{l}\text { Proposed } \\
\text { Method }\end{array}$ & & & & & \\
\hline & RMS: 0.4974 & RMS: 0.4802 & RMS: 0.4744 & RMS: 0.4887 & RMS: 0.4724 \\
\hline
\end{tabular}

Table 2. Comparison of PSNR and MSE result using a different method

\begin{tabular}{cccccc}
\hline & & DCP & HE & DECORR & Proposed Method \\
\hline PSNR & Scene 1 & 6.6143 & 12.6297 & 13.8147 & 18.1745 \\
& Scene 2 & 10.1975 & 13.8147 & 14.6662 & 17.7938 \\
& Scene 3 & 10.4347 & 14.8583 & 15.1158 & 18.0891 \\
& Scene 4 & 11.3917 & 14.6568 & 13.3509 & 17.1538 \\
& Scene 5 & 11.3284 & 13.8147 & 16.8198 & 18.2336 \\
MSE & Scene 1 & 1.4179 & 3.5491 & 2.7016 & 1.0045 \\
& Scene 2 & 6.2134 & 2.7016 & 2.0022 & 1.0807 \\
& Scene 3 & 5.8832 & 2.1245 & 2.2205 & 1.0096 \\
& Scene 4 & 4.7197 & 2.2254 & 3.0060 & 1.2523 \\
& Scene 5 & 4.7889 & 2.7016 & 1.3524 & 1.2432 \\
\hline
\end{tabular}

\subsection{Analysis of feature signatures}

Feature extraction allows for a more-accurate detection of features, as a result of the image's enhancements [15], [16], [39], [89], [143]-[145], [148]. The signature of feature classes could be distinguished from complex surface textures. Starting with image pre-processing through image 
enhancement, a comprehensive method of features extraction has been implemented, creating a useful representation of the developed areas, vegetation, sea, and natural ground. Image enhancement is applied to the initial image, in order to produce an enhanced image for purposes of better clarity. Canny edge detection [7], [117], [160] was used to detect shorelines. Neither the Sobel, Prewitt nor Log methods were able to detect shore edges. According to the results, the proposed method demonstrated the best edge detection. Minimum and maximum thresholds were tested. However, the threshold at 0.07 produces the best results. In DCP, the result showed the lowest detection when compared to other methods. In Scene 2, the edge could not be detected due to the image's low contrast. For HE, the edge detection in Scene 2 showed that the edge could not be detected due to the image's brightness. The image consisted of misclassified pixels. However, the proposed method showed the best shoreline edge detection. All the edges were detected, and almost all surface reflectance was removed. An image's level of contrast affects the shoreline detection results. By using the Canny edge detector as the edge detector for shorelines in the surface reflectance images, a robust and very-high enhancement level was achieved.

The improvement of overall performance evaluation provided a corrected input image and produced better feature extraction, when compared to the initial image. The average accuracy of the initial image for all datasets was $76.39 \%$, producing a low-quality contrast, due to the presence of surface reflectance. The DCP method for all datasets showed that the enhanced images produced a low quality of contrast with an accuracy that was about $89.78 \%$ and Kappa value was 0.86 as depicted in Table 3. As explained above, the enhanced image results of the HE method for all datasets, have produce more intensity values which achieved higher values for all datasets when compared with the DCP method. The average accuracy for all datasets is more than $80 \%$, while the Kappa value is more than 0.83 . For the DECORR, the enhanced image produced an $87.91 \%$ average accuracy for all datasets, while the mean of the Kappa value is 0.82 . The accuracy and Kappa value achieved a higher value for all data sets, when compared with the other methods. This result showed that the proposed method produced better results when classified with the four class features. These included vegetation areas, developed areas, natural ground and soil. The average accuracy for the proposed method was found to be more than $85 \%$, while the average of Kappa value was 0.88 .

Table 3. Performance evaluation

\begin{tabular}{|c|c|c|c|c|c|c|c|}
\hline & & Accuracy (\%) & Kappa & & & Accuracy (\%) & Kappa \\
\hline \multirow[t]{5}{*}{ Scene 1} & Initial Image & 82.09 & 0.73 & Scene 4 & Initial Image & 80.4 & 0.71 \\
\hline & DCP & 89.78 & 0.86 & & DCP & 83.14 & 0.8 \\
\hline & $\mathrm{HE}$ & 91.06 & 0.88 & & $\mathrm{HE}$ & 88.92 & 0.84 \\
\hline & DECORR & 91.96 & 0.89 & & DECORR & 92.12 & 0.88 \\
\hline & Proposed Method & 92.75 & 0.9 & & Proposed Method & 94.26 & 0.9 \\
\hline \multirow[t]{5}{*}{ Scene 2} & Initial Image & 68.58 & 0.55 & Scene 5 & Initial Image & 73.55 & 0.69 \\
\hline & DCP & 82.55 & 0.76 & & DCP & 86.24 & 0.82 \\
\hline & $\mathrm{HE}$ & 79.06 & 0.71 & & $\mathrm{HE}$ & 87.46 & 0.83 \\
\hline & DECORR & 84.09 & 0.78 & & DECORR & 89.67 & 0.85 \\
\hline & Proposed Method & 87.34 & 0.82 & & Proposed Method & 92.12 & 0.88 \\
\hline \multirow[t]{5}{*}{ Scene 3} & Initial Image & 78.5 & 0.69 & & & & \\
\hline & DCP & 86.99 & 0.81 & & & & \\
\hline & $\mathrm{HE}$ & 93.61 & 0.92 & & & & \\
\hline & DECORR & 86.57 & 0.8 & & & & \\
\hline & Proposed Method & 95.28 & 0.93 & & & & \\
\hline
\end{tabular}

\section{CONCLUSION}

In this study, an image enhancement method was proposed for low contrast images, formed due to the surface reflectance in SPOT-5 images. Therefore, a false colour composite, including the near-infrared (NIR), green and red channels, was chosen in order to increase the vegetation's contrast, as indicated in red. By using histogram equalization (HE), the image was adjusted in order to minimize the problem of darker spots or surface reflectance. The modification of the weight of the NIR channel made the vegetation reflect the NIR and green light. As a result, the NIR-HE method efficiently restored contrast for all datasets, producing a higher efficiency in edge detection, and achieving higher overall accuracy. Additionally, the root mean square (RMS) showed improved values. The accuracy and kappa value were obtained, in order to evaluate the maximum performance of the enhanced images. A success rate of more than $80 \%$ was achieved by using the proposed method, which proved that it could assist in high accuracy feature extraction.

\section{ACKNOWLEDGEMENT}

The authors gratefully acknowledge Universiti Teknologi MARA, Universiti Teknologi Malaysia, Universiti Kebangsaan Malaysia, Universiti Tun Hussein Onn and Universitas Ahmad Dahlan for supporting 
this collaborative research in the present work, and also would like to thank Malaysian Remote Sensing Agency, which provided SPOT-5 data; and the Malaysian Government and Department of Survey and Mapping Malaysia (JUPEM) which provided topography and gazettes related to the Tanjung Piai area. Tanjung Piai Johor National Park staff provided useful information about the study site. This research was supported by the Myth Scholarship Scheme of the Ministry of Education Malaysia and the G-Heart scheme under the Gates Scholars Foundation. We also humbly acknowledge the FRGS/1/2020/ICT02/UTM/03/1 of FRGS grant funded by the Ministry of Education, Malaysia.

\section{REFERENCES}

[1] R. Aedla, G. S. Dwarakish, and D. V. Reddy, "Automatic Shoreline Detection and Change Detection Analysis of Netravati-GurpurRivermouth Using Histogram Equalization and Adaptive Thresholding Techniques," Aquatic Procedia, vol. 4, pp. 563-570, 2015, doi: 10.1016/j.aqpro.2015.02.073.

[2] B. Chandrababu Naik and B. Anuradha, "Extraction of water-body area from high-resolution Landsat imagery," International Journal of Electrical and Computer Engineering (IJECE), vol. 8, no. 6. pp. 4111-4119, 2018, doi: 10.11591/ijece.v8i6.pp.4111-4119.

[3] Y. Shafiei, F. Faghihi, H. Heydari, and A. H. Salemi, "Laboratory investigation of the impact of air pollution on partial discharge inception voltage of insulators in a specific region," International Journal of Electrical and Computer Engineering (IJECE), vol. 11, no. 6. pp. 4634-4640, 2021, doi: 10.11591/ijece.v11i6.pp4634-4640.

[4] Y. Sari, P. B. Prakoso, and A. R. Baskara, "Application of neural network method for road crack detection," TELKOMNIKA (Telecommunication Computing Electronics and Control), vol. 18, no. 4. pp. 1962-1967, 2020, doi: 10.12928/TELKOMNIKA.V18I4.14825.

[5] N. M. Nawi, M. Makhtar, M. Z. Salikon, and Z. A. Afip, "A comparative analysis of classification techniques on predicting flood risk," Indonesian Journal of Electrical Engineering and Computer Science (IJEECS), vol. 18, no. 3, pp. 1342-1350, Jun. 2020, doi: 10.11591/ijeecs.v18.i3.pp1342-1350.

[6] M. A. Zaytar and C. El Amrani, "Satellite image inpainting with deep generative adversarial neural networks," IAES International Journal of Artificial Intelligence (IJ-AI), vol. 10, no. 1, pp. 121-130, Mar. 2021, doi: 10.11591/ijai.v10.i1.pp121-130.

[7] T. H. Phan, D. C. Tran, and M. F. Hassan, "Vietnamese character recognition based on CNN model with reduced character classes," Bulletin of Electrical Engineering and Informatics (BEEI), vol. 10, no. 2, pp. 962-969, Apr. 2021, doi: 10.11591/eei.v10i2.2810.

[8] Y. Yuhendra and J. T. S. Sumantyo, "Assessment of Landsat 8 TIRS data capability for the preliminary study of geothermal energy resources in West Sumatra," TELKOMNIKA (Telecommunication Computing Electronics and Control), vol. 18, no. 5, pp. 2737-2747, Oct. 2020, doi: 10.12928/telkomnika.v18i5.16172.

[9] I. S. Al-Mejibli, J. K. Alwan, and D. H. Abd, "The effect of gamma value on support vector machine performance with different kernels," International Journal of Electrical and Computer Engineering (IJECE), vol. 10, no. 5, pp. 5497-5506, Oct. 2020, doi: 10.11591/ijece.v10i5.pp5497-5506.

[10] M. R. Al-Hadidi, B. AlSaaidah, and M. Al-Gawagzeh, "Glioblastomas brain tumour segmentation based on convolutional neural networks," International Journal of Electrical and Computer Engineering (IJECE), vol. 10, no. 5, pp. 4738-4744, Oct. 2020, doi: 10.11591/ijece.v10i5.pp4738-4744.

[11] N. Sabri, N. Shafekah Kassim, S. Ibrahim, R. Roslan, N. N. A. Mangshor, and Z. Ibrahim, "Nutrient deficiency detection in Maize (Zea mays L.) leaves using image processing," IAES International Journal of Artificial Intelligence (IJ-AI), vol. 9, no. 2, pp. 304-309, Jun. 2020, doi: 10.11591/ijai.v9.i2.pp304-309.

[12] D. Febrian Sengkey, A. Jacobus, and F. Johanes Manoppo, "Effects of kernels and the proportion of training data on the accuracy of SVM sentiment analysis in lecturer evaluation," IAES International Journal of Artificial Intelligence (IJ-AI), vol. 9, no. 4, pp. 734-743, Dec. 2020, doi: 10.11591/ijai.v9.i4.pp734-743.

[13] C. Jittawiriyanukoon, "Estimation of regression-based model with bulk noisy data," International Journal of Electrical and Computer Engineering (IJECE), vol. 9, no. 5, pp. 3649-3656, Oct. 2019, doi: 10.11591/ijece.v9i5.pp3649-3656.

[14] M. Dimyati, A. Fauzy, and A. S. Putra, "Remote sensing technology for disaster mitigation and regional infrastructure planning in urban area: a review," TELKOMNIKA (Telecommunication Computing Electronics and Control), vol. 17, no. 2, pp. 601-608, Apr. 2019, doi: 10.12928/telkomnika.v17i2.12242.

[15] S. K. Jameel, S. Aydin, and N. H. Ghaeb, "Local information pattern descriptor for corneal diseases diagnosis," International Journal of Electrical and Computer Engineering, vol. 11, no. 6. pp. 4972-4981, 2021, doi: 10.11591/ijece.v11i6.pp4972-4981.

[16] A. N. Razzaq, R. Ghazali, N. K. El Abbadi, and H. A. H. Al Naffakh, "Levenberg-marquardt backpropagation neural network with techebycheve moments for face detection," Bulletin of Electrical Engineering and Informatics, vol. 10, no. 5. pp. 2548-2556, 2021, doi: 10.11591/eei.v10i5.2364.

[17] B. C. C. Meng, D. S. A. Damit, and N. S. Damanhuri, "Comparative studies of multiscale edge detection using different edge detectors for mri thigh," Bulletin of Electrical Engineering and Informatics, vol. 10, no. 4. pp. 19791986, 2021, doi: 10.11591/EEI.V10I4.2220.

[18] A. Abuhamdah, W. Boulila, G. M. Jaradat, A. M. Quteishat, M. K. Alsmadi, and I. A. Almarashdeh, "A novel population-based local search for nurse rostering problem," International Journal of Electrical and Computer Engineering, vol. 11, no. 1. pp. 471-480, 2021, doi: 10.11591/ijece.v11i1.pp471-480. 
[19] A. Hussein Ali, M. Nawaf Abbod, M. Khamees Khaleel, M. Abdulghafoor Mohammed, and T. Sutikno, "Large scale data analysis using MLlib," TELKOMNIKA (Telecommunication Computing Electronics and Control), vol. 19, no. 5, pp. 1735-1746, Oct. 2021, doi: 10.12928/telkomnika.v19i5.21059.

[20] M. Z. N. Al-Dabagh, "Automated tumor segmentation in MR brain image using fuzzy C-means clustering and seeded region methodology," IAES International Journal of Artificial Intelligence, vol. 10, no. 2. pp. 284-290, 2021, doi: 10.11591/ijai.v10.i2.pp284-290.

[21] S. Yakin, T. Hasanuddin, and N. Kurniati, "Application of content based image retrieval in digital image search system," Bulletin of Electrical Engineering and Informatics, vol. 10, no. 2. pp. 1122-1128, 2021, doi: 10.11591/EEI.V10I2.2713.

[22] D. Ghorai and G. S. Bhunia, "Automatic shoreline detection and its forecast: a case study on Dr. Abdul Kalam Island in the section of Bay of Bengal," Geocarto International, pp. 1-20, Sep. 2020, doi: 10.1080/10106049.2020.1815868.

[23] A. P. Ruiz-Beltran, A. Astorga-Moar, P. Salles, and C. M. Appendini, "Short-Term Shoreline Trend Detection Patterns Using SPOT-5 Image Fusion in the Northwest of Yucatan, Mexico," Estuaries and Coasts, vol. 42, no. 7, pp. 1761-1773, Nov. 2019, doi: 10.1007/s12237-019-00573-7.

[24] A. Widipaminto et al., "Roof materials identification based on pleiades spectral responses using supervised classification," TELKOMNIKA (Telecommunication Computing Electronics and Control), vol. 19, no. 2, pp. 690 704, Apr. 2021, doi: 10.12928/telkomnika.v19i2.18155.

[25] M. B. Saleh et al., "Algorithm for detecting deforestation and forest degradation using vegetation indices," Telkomnika (Telecommunication Computing Electronics and Control), vol. 17, no. 5. pp. 2335-2345, 2019, doi: 10.12928/TELKOMNIKA.v17i5.12585.

[26] C. Dewi and A. Basuki, "Identifying citronella plants from UAV imagery using support vector machine," Telkomnika (Telecommunication Computing Electronics and Control), vol. 16, no. 4. pp. 1877-1885, 2018, doi: 10.12928/TELKOMNIKA.v16i4.7450.

[27] R. A. Hamzah, M. M. Roslan, A. F. B. Kadmin, S. F. B. A. Gani, and K. A. A. Aziz, "JPG, PNG and BMP image compression using discrete cosine transform," Telkomnika (Telecommunication Computing Electronics and Control), vol. 19, no. 3. pp. 1010-1016, 2021, doi: 10.12928/TELKOMNIKA.v19i3.14758.

[28] M. C. G. Babu and M. C. Padma, "Semantic feature extraction method for hyperspectral crop classification," Indonesian Journal of Electrical Engineering and Computer Science, vol. 23, no. 1. pp. 387-395, 2021, doi: 10.11591/ijeecs.v23.i1.pp387-395.

[29] W.-W. Chen and H.-K. Chang, "Estimation of shoreline position and change from satellite images considering tidal variation," Estuarine, Coastal and Shelf Science, vol. 84, no. 1, pp. 54-60, Aug. 2009, doi: 10.1016/j.ecss.2009.06.002.

[30] E. I. Journal, "How to interpret a false color satellite image." 2021, [Online]. Available: http://eijournal.com/print/articles/how-to-interpret-a-false-color-satellite-image.

[31] B. Castelle et al., "Satellite-derived shoreline detection at a high-energy meso-macrotidal beach," Geomorphology, vol. 383. 2021, doi: 10.1016/j.geomorph.2021.107707.

[32] Y. Tajima, L. Wu, and K. Watanabe, "Development of a shoreline detection method using an artificial neural network based on satellite sar imagery," Remote Sensing, vol. 13, no. 12. 2021, doi: 10.3390/rs13122254.

[33] S. Dhingra and D. Kumar, "A review of remotely sensed satellite image classification," International Journal of Electrical and Computer Engineering, vol. 9, no. 3. pp. 1720-1731, 2019, doi: 10.11591/ijece.v9i3.pp.1720-1731.

[34] M. S. Al Gobi, D. Benatia, and M. Bali, "A hybrid algorithm for wave-front corrections applied to satellite-toground laser communication," Telkomnika (Telecommunication Computing Electronics and Control), vol. 18, no. 3. pp. 1259-1267, 2020, doi: 10.12928/TELKOMNIKA.v18i3.12960.

[35] F. Ribas, G. Simarro, J. Arriaga, and P. Luque, "Automatic shoreline detection from video images by combining information from different methods," Remote Sensing, vol. 12, no. 22. pp. 1-23, 2020, doi: 10.3390/rs12223717.

[36] S. Hożyń and J. Zalewski, "Shoreline detection and land segmentation for autonomous surface vehicle navigation with the use of an optical system," Sensors (Switzerland), vol. 20, no. 10. 2020, doi: 10.3390/s20102799.

[37] D. Furberg, Y. Ban, and A. Nascetti, "Monitoring of urbanization and analysis of environmental impact in Stockholm with Sentinel-2A and SPOT-5 Multispectral Data," Remote Sensing, vol. 11, no. 20. 2019, doi: $10.3390 / \mathrm{rs} 11202408$.

[38] R. P. Silalahi, I. N. S. Jaya, T. Tiryana, and F. Mulia, "Assessing the crown closure of nypa on UAV images using mean-shift segmentation algorithm," Indonesian Journal of Electrical Engineering and Computer Science, vol. 9, no. 3. pp. 722-730, 2018, doi: 10.11591/ijeecs.v9.i3.pp722-730.

[39] S. L. K. Reddy, C. V Rao, P. Rajesh Kumar, R. V. G. Anjaneyulu, and B. Gopala Krishna, "An index based road feature extraction from LANDSAT-8 OLI images," International Journal of Electrical and Computer Engineering, vol. 11, no. 2. pp. 1319-1336, 2021, doi: 10.11591/ijece.v11i2.pp1319-1336.

[40] B. Iskandar, I. N. S. Jaya, and M. B. Saleh, "Crown closure segmentation on wetland lowland forest using the mean shift algorithm," Indonesian Journal of Electrical Engineering and Computer Science, vol. 24, no. 2. pp. 965-977, 2021, doi: 10.11591/ijeecs.v24.i2.pp965-977.

[41] J.-H. Kim, W.-D. Jang, J.-Y. Sim, and C.-S. Kim, "Optimized contrast enhancement for real-time image and video dehazing," Journal of Visual Communication and Image Representation, vol. 24, no. 3, pp. 410-425, Apr. 2013 , doi: 10.1016/j.jvcir.2013.02.004.

[42] J. Long, Z. Shi, W. Tang, and C. Zhang, "Single Remote Sensing Image Dehazing," IEEE Geoscience and Remote Sensing Letters, vol. 11, no. 1, pp. 59-63, Jan. 2014, doi: 10.1109/LGRS.2013.2245857.

[43] "Malaysia Meteorological Department.” 2018, [Online]. Available: http://www.met.gov.my.

Integrated NIR-HE based SPOT-5 image enhancement method for features ... (Farizuwana Akma Zulkifle) 
[44] K. M. K. Ku Yusof, S. S. Ismail, A. Azid, M. S. A. Sani, N. M. Isa, and M. Z. Mohamat Zawawi, "Variability on particulate matter and meteorology dataset during the hazy period in eastern region of Peninsular Malaysia," Data in Brief, vol. 29. 2020, doi: 10.1016/j.dib.2020.105210.

[45] Y.-H. Shiau, P.-Y. Chen, H.-Y. Yang, C.-H. Chen, and S.-S. Wang, "Weighted haze removal method with halo prevention," Journal of Visual Communication and Image Representation, vol. 25, no. 2, pp. 445-453, Feb. 2014, doi: 10.1016/j.jvcir.2013.12.011.

[46] B. A. Schichtel et al., "Using IMPROVE speciated aerosol concentrations to track trends in anthropogenic haze," vol. 3. pp. 2251-2258, 2015, doi: 10.1016/j.atmosres.2018.05.008.

[47] L. Pei, Z. Yan, D. Chen, and S. Miao, "Climate variability or anthropogenic emissions: which caused Beijing Haze?," Environmental Research Letters, vol. 15, no. 3. 2020, doi: 10.1088/1748-9326/ab6f11.

[48] S. Y. J. Prasetyo, B. H. Simanjuntak, K. D. Hartomo, and W. Sulistyo, "Computer model for tsunami vulnerability using sentinel 2a and srtm images optimized by machine learning," Bulletin of Electrical Engineering and Informatics, vol. 10, no. 5. pp. 2821-2835, 2021, doi: 10.11591/eei.v10i5.3100.

[49] M. H. X. Wai, A. Huong, and X. Ngu, "Soil moisture level prediction using optical technique and artificial neural network," International Journal of Electrical and Computer Engineering, vol. 11, no. 2. pp. 1752-1760, 2021, doi: 10.11591/ijece.v11i2.pp1752-1760.

[50] M. Dimyati, Kustiyo, and R. D. Dimyati, "Paddy field classification with MODIS-terra multi-temporal image transformation using phenological approach in Java Island," International Journal of Electrical and Computer Engineering, vol. 9, no. 2. pp. 1346-1358, 2019, doi: 10.11591/ijece.v9i2.pp.1346-1358.

[51] A. Al Fugura, L. Billa, and B. Pradhan, "Semi-automated procedures for shoreline extraction using single RADARSAT-1 SAR image," Estuarine, Coastal and Shelf Science, vol. 95, no. 4, pp. 395-400, Dec. 2011, doi: 10.1016/j.ecss.2011.10.009.

[52] Q. A. Al-hussain Hadi, "Vein palm recognition model using fusion of features," Telkomnika (Telecommunication Computing Electronics and Control), vol. 18, no. 6, pp. 2921-2927, 2020, doi: 10.12928/TELKOMNIKA.v18i6.16149.

[53] K. I. Ahmed, M. H. Habaebi, and M. R. Islam, "A real time vein detection system," Indonesian Journal of Electrical Engineering and Computer Science, vol. 10, no. 1. pp. 129-137, 2018, doi: 10.11591/IJEECS.V10.I1.PP129-137.

[54] K. I. Ahmed, M. H. Habaebi, and M. D. Islam, "Smartphone aided real-time blood vein detection system," Bulletin of Electrical Engineering and Informatics, vol. 8, no. 3. pp. 1096-1107, 2019, doi: 10.11591/eei.v8i3.1514.

[55] M. A. Anwer, S. M. Shareef, and A. M. Ali, "Accident vehicle types classification: A comparative study between different deep learning models," Indonesian Journal of Electrical Engineering and Computer Science, vol. 21, no. 3. pp. 1474-1484, 2021, doi: 10.11591/ijeecs.v21.i3.pp1474-1484.

[56] A. A. Alabdel Abass and N. P. Divvala, "An enhanced OFDM light weight physical layer encryption scheme," International Journal of Electrical and Computer Engineering, vol. 11, no. 3. pp. 2178-2190, 2021, doi: 10.11591/ijece.v11i3.pp2178-2190.

[57] Handoko, J. H. Pratama, and B. W. Yohanes, "Traffic sign detection optimization using color and shape segmentation as pre-processing system," Telkomnika (Telecommunication Computing Electronics and Control), vol. 19, no. 1. pp. 173-181, 2021, doi: 10.12928/TELKOMNIKA.V19I1.16281.

[58] M. Ahmed, M. Salleh, M. I. Channa, and M. F. Rohani, "Energy efficient routing protocols for UWSN: A review," Telkomnika (Telecommunication Computing Electronics and Control), vol. 15, no. 1. pp. 212-219, 2017, doi: 10.12928/TELKOMNIKA.v15i1.4706.

[59] I. S. Amiri and S. E. Alavi, "Several mode-locked pulses generation and transmission over soliton based optical transmission link," Indonesian Journal of Electrical Engineering and Computer Science, vol. 1, no. 2. pp. 288-293, 2016, doi: 10.11591/ijeecs.v1.i2.pp288-293.

[60] T. Negara, I. N. S. Jaya, C. Kusmana, I. Mansur, and N. A. Santi, "Drone image-based parameters for assessing the vegetation condition the reclamation success in post-mining oil exploration," Telkomnika (Telecommunication Computing Electronics and Control), vol. 19, no. 1. pp. 105-114, 2021, doi: 10.12928/TELKOMNIKA.V19I1.16663.

[61] H. M. El-Hageen, A. M. Alatwi, and A. N. Z. Rashed, "Laser measured rate equations with various transmission coders for optimum of data transmission error rates," Indonesian Journal of Electrical Engineering and Computer Science, vol. 20, no. 3. pp. 1406-1412, 2020, doi: 10.11591/ijeecs.v20.i3.pp1406-1412.

[62] S. H. Ern, A. Huong, W. M. Hafizah Wan Mahmud, and X. Ngu, "Portable and wireless imaging of dorsal hand vein," Indonesian Journal of Electrical Engineering and Computer Science, vol. 19, no. 2. pp. 693-700, 2020, doi: 10.11591/ijeecs.v19.i2.pp693-700.

[63] I. S. Amiri, A. N. Z. Rashed, and P. Yupapin, "Influence of device to device interconnection elements on the system behavior and stability," Indonesian Journal of Electrical Engineering and Computer Science, vol. 18, no. 2. pp. 843-847, 2020, doi: 10.11591/ijeecs.v18.i2.pp843-847.

[64] I. S. Amiri, A. N. Z. Rashed, and P. Yupapin, "Z Shaped like resonator with crystal in the presence of flat mirror based standing wave ratio for optical antenna systems," Indonesian Journal of Electrical Engineering and Computer Science, vol. 17, no. 3. pp. 1405-1409, 2019, doi: 10.11591/ijeecs.v17.i3.pp1405-1409.

[65] I. S. Amiri and A. N. Zaki Rashed, "Simulative study of simple ring resonator-based brewster plate for power system operation stability," Indonesian Journal of Electrical Engineering and Computer Science, vol. 16, no. 2. pp. 1070-1076, 2019, doi: 10.11591/ijeecs.v16.i2.pp1070-1076. 
[66] I. S. Amiri and A. N. Z. Rashed, "Numerical investigation of V shaped three elements resonator for optical closed loop system," Indonesian Journal of Electrical Engineering and Computer Science, vol. 16, no. 3. pp. 1392-1397, 2019, doi: 10.11591/ijeecs.v16.i3.pp1392-1397.

[67] S. J. Elias, M. N. M. Warip, M. Elshaikh, M. Y. Darus, and R. B. Ahmad, "802.11p optimization for delay sensitive in non-safety messages in VANETs," Indonesian Journal of Electrical Engineering and Computer Science, vol. 12, no. 1. pp. 201-207, 2018, doi: 10.11591/ijeecs.v12.i1.pp201-207.

[68] C. Feng, S. Zhuo, X. Zhang, L. Shen, and S. Susstrunk, "Near-infrared guided color image dehazing," in 2013 IEEE International Conference on Image Processing, Sep. 2013, pp. 2363-2367, doi: 10.1109/ICIP.2013.6738487.

[69] T. Kuleli, A. Guneroglu, F. Karsli, and M. Dihkan, "Automatic detection of shoreline change on coastal Ramsar wetlands of Turkey," Ocean Engineering, vol. 38, no. 10, pp. 1141-1149, Jul. 2011, doi: 10.1016/j.oceaneng.2011.05.006.

[70] S. Mungmode, R. R. Sedamkar, and N. Kulkarni, "A Modified High Frequency Adaptive Security Approach using Steganography for Region Selection based on Threshold Value," Procedia Computer Science, vol. 79, pp. 912-921, 2016, doi: 10.1016/j.procs.2016.03.114.

[71] L. Roupioz, F. Nerry, L. Jia, and M. Menenti, "Improved Surface Reflectance from Remote Sensing Data with SubPixel Topographic Information," Remote Sensing, vol. 6, no. 11, pp. 10356-10374, Oct. 2014, doi: $10.3390 /$ rs61110356.

[72] G. Raju and M. S. Nair, "A fast and efficient color image enhancement method based on fuzzy-logic and histogram," AEU - International Journal of Electronics and Communications, vol. 68, no. 3, pp. 237-243, Mar. 2014, doi: 10.1016/j.aeue.2013.08.015.

[73] K. He, J. Sun, and X. Tang, "Guided Image Filtering," IEEE Transactions on Pattern Analysis and Machine Intelligence, vol. 35, no. 6, pp. 1397-1409, Jun. 2013, doi: 10.1109/TPAMI.2012.213.

[74] Kaiming He, Jian Sun, and Xiaoou Tang, "Single Image Haze Removal Using Dark Channel Prior," IEEE Transactions on Pattern Analysis and Machine Intelligence, vol. 33, no. 12, pp. 2341-2353, Dec. 2011, doi: 10.1109/TPAMI.2010.168.

[75] N. H. Kaplan, "Remote sensing image enhancement using hazy image model," Optik, vol. 155, pp. 139-148, Feb. 2018, doi: 10.1016/j.ijleo.2017.10.132.

[76] S. G. Narasimhan and S. K. Nayar, "Contrast restoration of weather degraded images," IEEE Transactions on Pattern Analysis and Machine Intelligence, vol. 25, no. 6, pp. 713-724, Jun. 2003, doi: 10.1109/TPAMI.2003.1201821.

[77] S. G. Narasimhan and S. K. Nayar, "Removing weather effects from monochrome images," in Proceedings of the 2001 IEEE Computer Society Conference on Computer Vision and Pattern Recognition. CVPR 2001, 2001, vol. 2, pp. II-186-II-193, doi: 10.1109/CVPR.2001.990956.

[78] I. Yoon, S. Kim, D. Kim, M. Hayes, and J. Paik, "Adaptive defogging with color correction in the HSV color space for consumer surveillance system," IEEE Transactions on Consumer Electronics, vol. 58, no. 1, pp. 111-116, Feb. 2012, doi: 10.1109/TCE.2012.6170062.

[79] J. B. C. Randolph H. Wynne, Introduction to Remote Sensing, 5th ed. Guilford Press, 2011.

[80] S.-C. Huang, B.-H. Chen, and W.-J. Wang, "Visibility Restoration of Single Hazy Images Captured in Real-World Weather Conditions," IEEE Transactions on Circuits and Systems for Video Technology, vol. 24, no. 10, pp. 18141824, Oct. 2014, doi: 10.1109/TCSVT.2014.2317854.

[81] R. T. Tan, "Visibility in bad weather from a single image," in 2008 IEEE Conference on Computer Vision and Pattern Recognition, Jun. 2008, pp. 1-8, doi: 10.1109/CVPR.2008.4587643.

[82] X. Liu, H. Zhang, Y. Cheung, X. You, and Y. Y. Tang, "Efficient single image dehazing and denoising: An efficient multi-scale correlated wavelet approach," Computer Vision and Image Understanding, vol. 162, pp. 2333, Sep. 2017, doi: 10.1016/j.cviu.2017.08.002.

[83] ARCGIS, "No Title," 2021.

[84] P. Patil, C. M. Sheela Rani, and M. Arya, "A hybrid Pan-sharpening approach using maximum local extrema," International Journal of Electrical and Computer Engineering, vol. 9, no. 1. pp. 255-263, 2019, doi: 10.11591/ijece.v9i1.pp255-263.

[85] A. Pourkashani, A. Shahbahrami, and A. Akoushideh, "Copy-move forgery detection using convolutional neural network and K-mean clustering," International Journal of Electrical and Computer Engineering, vol. 11, no. 3. pp. 2604-2612, 2021, doi: 10.11591/ijece.v11i3.pp2604-2612.

[86] M. H. Hamd and R. A. Rasool, "Towards better performance: phase congruency based face recognition," Telkomnika (Telecommunication Computing Electronics and Control), vol. 18, no. 6. pp. 3041-3049, 2020, doi: 10.12928/TELKOMNIKA.v18i6.17300.

[87] R. D. Dimyati, P. Danoedoro, Hartono, and Kustiyo, "A minimum cloud cover mosaic image model of the operational land imager landsat-8 multitemporal data using tile based," International Journal of Electrical and Computer Engineering, vol. 8, no. 1. pp. 360-371, 2018, doi: 10.11591/ijece.v8i1.pp360-371.

[88] D. P. Apriyanto, I. N. S. Jaya, and N. Puspaningsih, "Examining the object-based and pixel-based image analyses for developing stand volume estimator model," Indonesian Journal of Electrical Engineering and Computer Science, vol. 15, no. 3. pp. 1586-1596, 2019, doi: 10.11591/ijeecs.v15.i3.pp1586-1596.

[89] H. Elmannai, M. S. Naceur, M. A. Loghmari, and A. AlGarni, "A new feature extraction approach based on non linear source separation," International Journal of Electrical and Computer Engineering, vol. 11, no. 5. pp. 4082 4094, 2021, doi: 10.11591/ijece.v11i5.pp4082-4094. 
[90] N. P. More, V. B. Nikam, and B. Banerjee, "Novel approach of association rule mining for tree canopy assessment," IAES International Journal of Artificial Intelligence, vol. 10, no. 3. pp. 771-779, 2021, doi: 10.11591/ijai.v10.i3.pp771-779.

[91] A. Wenda, I. Permana, Yusmar, and N. N. Kurniawati, "Identification of paddy leaf diseases based on texture analysis of blobs and color segmentation," Telkomnika (Telecommunication Computing Electronics and Control), vol. 18, no. 4. pp. 2018-2026, 2020, doi: 10.12928/TELKOMNIKA.V18I4.14614.

[92] B. N. Shah and J. K. Bhalani, "Comparative analysis and implementation of structured edge active contour," International Journal of Electrical and Computer Engineering, vol. 10, no. 2. pp. 1842-1848, 2020, doi: 10.11591/ijece.v10i2.pp1842-1848.

[93] S. B. Jadhav, V. R. Udupi, and S. B. Patil, "Convolutional neural networks for leaf image-based plant disease classification," IAES International Journal of Artificial Intelligence, vol. 8, no. 4. pp. 328-341, 2019, doi: 10.11591/ijai.v8.i4.pp328-341.

[94] K. M. Rao, B. S. Rao, B. S. Chandana, and J. Harikiran, "Dimensionality reduction and hierarchical clustering in framework for hyperspectral image segmentation," Bulletin of Electrical Engineering and Informatics, vol. 8, no. 3. pp. 1081-1087, 2019, doi: 10.11591/eei.v8i3.1451.

[95] N. Radha and T. R. Babu, "Performance evaluation of quarter shift dual tree complex wavelet transform based multifocus image fusion using fusion rules," International Journal of Electrical and Computer Engineering, vol. 9, no. 4. pp. 2377-2385, 2019, doi: 10.11591/ijece.v9i4.pp2377-2385.

[96] N. S. M. Noor, N. M. Saad, A. R. Abdullah, and N. M. Ali, "Automated segmentation and classification technique for brain stroke," International Journal of Electrical and Computer Engineering, vol. 9, no. 3. pp. 1832-1841, 2019, doi: 10.11591/ijece.v9i3.pp1832-1841.

[97] N. Bhat, U. Eranna, and M. K. Singh, "Pattern approximation based generalized image noise reduction using adaptive feedforward neural network," International Journal of Electrical and Computer Engineering, vol. 8, no. 6. pp. 5021-5031, 2018, doi: 10.11591/ijece.v8i6.pp.5021-5031.

[98] R. H. Altaie, "Restoration for blurred noisy images based on guided filtering and inverse filter," International Journal of Electrical and Computer Engineering, vol. 11, no. 2. pp. 1265-1275, 2021, doi: 10.11591/ijece.v11i2.pp1265-1275.

[99] A. Salam, A. E. Hibaoui, and A. Saif, "A comparison of activation functions in multilayer neural network for predicting the production and consumption of electricity power," International Journal of Electrical and Computer Engineering, vol. 11, no. 1. pp. 163-170, 2021, doi: 10.11591/ijece.v11i1.pp163-170.

[100] D. A. Umarhadi and P. Danoedoro, "Comparing canopy density measurement from UAV and hemispherical photography: An evaluation for medium resolution of remote sensing-based mapping," International Journal of Electrical and Computer Engineering, vol. 11, no. 1. pp. 356-364, 2021, doi: 10.11591/ijece.v11i1.pp356-364.

[101] J. E. Aurelia, Z. Rustam, I. Wirasati, S. Hartini, and G. S. Saragih, "Hepatitis classification using support vector machines and random forest," IAES International Journal of Artificial Intelligence, vol. 10, no. 2. pp. 446-451, 2021, doi: 10.11591/IJAI.V10.I2.PP446-451.

[102] M. Muller, S. Vincent, and O. P. Kumar, "Prediction of land-change using machine learning for the deforestation in paraguay," Bulletin of Electrical Engineering and Informatics, vol. 9, no. 5. pp. 1774-1782, 2020, doi: 10.11591/eei.v9i5.2532.

[103] M. Mahmood, B. Al-Khateeb, and W. M. Alwash, "A review on neural networks approach on classifying cancers," IAES International Journal of Artificial Intelligence, vol. 9, no. 2. pp. 317-326, 2020, doi: 10.11591/ijai.v9.i2.pp317-326.

[104] S. Y. J. Prasetyo, K. D. Hartomo, M. C. Paseleng, D. W. Chandra, and E. Winarko, "Satellite imagery and machine learning for aridity disaster classification using vegetation indices," Bulletin of Electrical Engineering and Informatics, vol. 9, no. 3. pp. 1149-1158, 2020, doi: 10.11591/eei.v9i3.1916.

[105] M. H. Hamd and R. A. Rasool, "Optimized multimodal biometric system based fusion technique for human identification," Bulletin of Electrical Engineering and Informatics, vol. 9, no. 6. pp. 2411-2418, 2020, doi: 10.11591/eei.v9i6.2632.

[106] M. H. N. Thi, N. T. P. Loan, T. M. Bui, and H. Van Ngoc, "Using CaCO3-doped package to improve correlated color temperature uniformity of white light-emitting diodes," International Journal of Electrical and Computer Engineering, vol. 11, no. 6. pp. 4817-4824, 2021, doi: 10.11591/ijece.v11i6.pp4817-4824.

[107] A. Al Mamun, M. S. Hossain, P. P. Em, A. Tahabilder, R. Sultana, and M. A. Islam, "Small intestine bleeding detection using color threshold and morphological operation in WCE images," International Journal of Electrical and Computer Engineering, vol. 11, no. 4. pp. 3040-3048, 2021, doi: 10.11591/ijece.v11i4.pp3040-3048.

[108] A. Al Mamun, P. P. Em, T. Ghosh, M. M. Hossain, M. G. Hasan, and M. G. Sadeque, "Bleeding recognition technique in wireless capsule endoscopy images using fuzzy logic and principal component analysis," International Journal of Electrical and Computer Engineering, vol. 11, no. 3. pp. 2688-2695, 2021, doi: 10.11591/ijece.v11i3.pp2688-2695.

[109] Y.-Y. Hou et al., "Rikitake dynamo system, its circuit simulation and chaotic synchronization via quasi-sliding mode control," Telkomnika (Telecommunication Computing Electronics and Control), vol. 19, no. 4. pp. 14281438, 2021, doi: 10.12928/TELKOMNIKA.v19i4.17700.

[110] M. J. Mohsin, W. K. Saad, B. J. Hamza, and W. A. Jabbar, "Performance analysis of image transmission with various channel conditions/modulation techniques," Telkomnika (Telecommunication Computing Electronics and Control), vol. 18, no. 3. pp. 1158-1168, 2020, doi: 10.12928/TELKOMNIKA.v18i3.14172. 
[111] N. A. Mohamed and M. A. Zulkifley, "Moving object detection via TV-L1 optical flow in fall-down videos," Bulletin of Electrical Engineering and Informatics, vol. 8, no. 3. pp. 839-846, 2019, doi: 10.11591/eei.v8i3.1346.

[112] G. Ramkumar and E. Logashanmugam, "Multimodal verge for scale and pose variant real time face tracking and recognition," Indonesian Journal of Electrical Engineering and Computer Science, vol. 13, no. 2. pp. 665-670, 2019, doi: 10.11591/ijeecs.v13.i2.pp665-670.

[113] M. Dimyati, R. D. Dimyati, Kustiyo, P. Danoedoro, and Hartono, "Interpretability evaluation of annual mosaic image of MTB model for land cover changes analysis," Telkomnika (Telecommunication Computing Electronics and Control), vol. 16, no. 3. pp. 934-945, 2018, doi: 10.12928/TELKOMNIKA.v16i3.9331.

[114] P. Prakash Tunga and V. Singh, "Compression of MRI brain images based on automatic extraction of tumor region," International Journal of Electrical and Computer Engineering, vol. 11, no. 5. pp. 3964-3976, 2021, doi: 10.11591/ijece.v11i5.pp3964-3976.

[115] N. A. Zainudin, A. Nazari, M. M. Mustafa, W. N. Wan Zakaria, N. S. Suriani, and W. N. H. Wan Kairuddin, "Glaucoma detection of retinal images based on boundary segmentation," Indonesian Journal of Electrical Engineering and Computer Science, vol. 18, no. 1.pp. 377-384, 2020, doi: 10.11591/ijeecs.v18.i1.pp377-384.

[116] S. Sinthuja and S. Saravanan, "GIS based satellite image denoising using curvelet transform," Indonesian Journal of Electrical Engineering and Computer Science, vol. 8, no. 3. pp. 654-656, 2017, doi: 10.11591/ijeecs.v8.i3.pp654-656.

[117] S. Yasmin and M. M. Rana, "Performance study of soft local binary pattern over local binary pattern under noisy images," International Journal of Electrical and Computer Engineering, vol. 6, no. 3. pp. 1161-1167, 2016, doi: 10.11591/ijece.v6i3.8383.

[118] H. M. Hammed, O. M. Hilal Almiahi, and O. Shauchuk, "Detection of anthropogenic objects based on the spatial characteristics of their contour in aerial image," Indonesian Journal of Electrical Engineering and Computer Science, vol. 23, no. 1. pp. 206-215, 2021, doi: 10.11591/ijeecs.v23.i1.pp206-215.

[119] A. A. Maryoosh, Z. S. Dhaif, and R. A. Mustafa, "Image confusion and diffusion based on multi-chaotic system and mix-column," Bulletin of Electrical Engineering and Informatics, vol. 10, no. 4. pp. 2100-2109, 2021, doi: 10.11591/eei.v10i4.2942.

[120] N. Gilbert and A. Rusli, "Single object detection to support requirements modeling using faster R-CNN," Telkomnika (Telecommunication Computing Electronics and Control), vol. 18, no. 2. pp. 830-838, 2020, doi: 10.12928/TELKOMNIKA.V18I2.14838.

[121] N. K. EL Abbadi and E. Saleem, "Automatic gray images colorization based on lab color space," Indonesian Journal of Electrical Engineering and Computer Science, vol. 18, no. 3. pp. 1501-1509, 2020, doi: 10.11591/ijeecs.v18.i3.pp1501-1509.

[122] C. R. Revanna and C. Keshavamurthy, "A new partial image encryption method for document images using variance based quad tree decomposition," International Journal of Electrical and Computer Engineering, vol. 10, no. 1. pp. 786-800, 2020, doi: 10.11591/ijece.v10i1.pp786-800.

[123] C. Solomon and T. Breckon, Fundamentals of Digital Image Processing: A practical approach with examples in Matlab. John Wiley \& Sons, 2011.

[124] A. S. Hamzah and A. Mohamed, "Classification of white rice grain quality using ann: A review," IAES International Journal of Artificial Intelligence, vol. 9, no. 4, pp. 600-608, 2020, doi: 10.11591/ijai.v9.i4.pp600-608.

[125] W. Setiawan, M. I. Utoyo, and R. Rulaningtyas, "Classification of neovascularization using convolutional neural network model," Telkomnika (Telecommunication Computing Electronics and Control), vol. 17, no. 1. pp. 463472, 2019, doi: 10.12928/TELKOMNIKA.v17i1.11604.

[126] F. I. M. Redzuan and M. Yusoff, "Knots timber detection and classification with C-support vector machine," Bulletin of Electrical Engineering and Informatics, vol. 8, no. 1. pp. 246-252, 2019, doi: 10.11591/eei.v8i1.1444.

[127] W. Wiharto, E. Suryani, and Y. R. Putra, "Classification of blast cell type on acute myeloid leukemia (AML) based on image morphology of white blood cells," Telkomnika (Telecommunication Computing Electronics and Control), vol. 17, no. 2. pp. 645-652, 2019, doi: 10.12928/TELKOMNIKA.V17I2.8666.

[128] Z. Saringat, A. Mustapha, R. D. R. Saedudin, and N. A. Samsudin, "Comparative analysis of classification algorithms for chronic kidney disease diagnosis," Bulletin of Electrical Engineering and Informatics, vol. 8, no. 4. pp. 1496-1501, 2019, doi: 10.11591/eei.v8i4.1621.

[129] G. A. Kaya and N. A. M. Kamal, "Feature selection for human membrane protein type classification using filter methods," IAES International Journal of Artificial Intelligence, vol. 8, no. 4. pp. 375-381, 2019, doi: 10.11591/ijai.v8.i4.pp375-381.

[130] H. Riri, M. Ed-Dhahraouy, A. Elmoutaouakkil, A. Beni-Hssane, and F. Bourzgui, "Extracted features based multiclass classification of orthodontic images," International Journal of Electrical and Computer Engineering, vol. 10, no. 4. pp. 3558-3567, 2020, doi: 10.11591/ijece.v10i4.pp3558-3567.

[131] M. Syarief and W. Setiawan, "Convolutional neural network for maize leaf disease image classification," Telkomnika (Telecommunication Computing Electronics and Control), vol. 18, no. 3. pp. 1376-1381, 2020, doi: 10.12928/TELKOMNIKA.v18i3.14840.

[132] S. Ibrahim, S. B. A. Kamaruddin, A. Zabidi, and N. A. M. Ghani, "Contrastive analysis of rice grain classification techniques: Multi-class support vector machine vs artificial neural network," IAES International Journal of Artificial Intelligence, vol. 9, no. 4. pp. 616-622, 2020, doi: 10.11591/ijai.v9.i4.pp616-622.

[133] N. D. Abdullah, U. R. Hashim, S. Ahmad, and L. Salahuddin, "Analysis of texture features for wood defect classification," Bulletin of Electrical Engineering and Informatics, vol. 9, no. 1. pp. 121-128, 2020, doi: 10.11591/eei.v9i1.1553. 
[134] C. Aroef, Y. Rivan, and Z. Rustam, "Comparing random forest and support vector machines for breast cancer classification," Telkomnika (Telecommunication Computing Electronics and Control), vol. 18, no. 2. pp. 815-821, 2020, doi: 10.12928/TELKOMNIKA.V18I2.14785.

[135] M. K. Alsmadi, M. Tayfour, R. A. Alkhasawneh, U. Badawi, I. Almarashdeh, and F. Haddad, "Robust feature extraction methods for general fish classification," International Journal of Electrical and Computer Engineering, vol. 9, no. 6, pp. 5192-5204, 2019, doi: 10.11591/ijece.v9i6.pp5192-5204.

[136] A. E. Minarno, F. D. S. Sumadi, H. Wibowo, and Y. Munarko, "Classification of batik patterns using K-nearest neighbor and support vector machine,” Bulletin of Electrical Engineering and Informatics, vol. 9, no. 3. pp. 1260 1267, 2020, doi: 10.11591/eei.v9i3.1971.

[137] H. A. Aliyu, M. A. A. Razak, R. Sudirman, and N. Ramli, “A deep learning alexnet model for classification of red blood cells in sickle cell anemia," IAES International Journal of Artificial Intelligence, vol. 9, no. 2. pp. 221-228, 2020, doi: 10.11591/ijai.v9.i2.pp221-228.

[138] A. A. Fauzi, F. Utaminingrum, and F. Ramdani, "Road surface classification based on LBP and GLCM features using KNN classifier," Bulletin of Electrical Engineering and Informatics, vol. 9, no. 4. pp. 1446-1453, 2020, doi: 10.11591/eei.v9i4.2348.

[139] T. Subba Reddy and J. Harikiran, "Hyperspectral image classification using support vector machines," IAES International Journal of Artificial Intelligence, vol. 9, no. 4. pp. 684-690, 2020, doi: 10.11591/ijai.v9.i4.pp684-690.

[140] R. S. El-Sayed and M. N. El-Sayed, "Classification of vehicles' types using histogram oriented gradients: Comparative study and modification," IAES International Journal of Artificial Intelligence, vol. 9, no. 4. pp. 700712, 2020, doi: 10.11591/ijai.v9.i4.pp700-712.

[141] J. J. Patel and S. K. Hadia, "An enhancement of mammogram images for breast cancer classification using artificial neural networks," IAES International Journal of Artificial Intelligence, vol. 10, no. 2. pp. 332-345, 2021, doi: 10.11591/ijai.v10.i2.pp332-345.

[142] J. E. Aurelia, Z. Rustam, and I. Wirasati, "Cervical cancer classification using convolutional neural networksupport vector machine," Telkomnika (Telecommunication Computing Electronics and Control), vol. 19, no. 5. pp. 1605-1611, 2021, doi: 10.12928/TELKOMNIKA.v19i5.20406.

[143] A. AlDabbas and Z. Gal, "Cassini-Huygens mission images classification framework by deep learning advanced approach," International Journal of Electrical and Computer Engineering, vol. 11, no. 3. pp. 2457-2466, 2021, doi: 10.11591/ijece.v11i3.pp2457-2466.

[144] Z. Rustam, A. Purwanto, S. Hartini, and G. S. Saragih, "Lung cancer classification using fuzzy C-means and fuzzy Kernel C-means based on CT scan image," IAES International Journal of Artificial Intelligence, vol. 10, no. 2. pp. 291-297, 2021, doi: 10.11591/ijai.v10.i2.pp291-297.

[145] M. A. Rasyidi, T. Bariyah, Y. I. Riskajaya, and A. D. Septyani, "Classification of handwritten javanese script using random forest algorithm," Bulletin of Electrical Engineering and Informatics, vol. 10, no. 3. pp. 1308-1315, 2021, doi: 10.11591/eei.v10i3.3036.

[146] G. Jayagopi and S. Pushpa, "On the classification of arrhythmia using supplementary features from tetrolet transforms," International Journal of Electrical and Computer Engineering, vol. 9, no. 6, pp. 5006-5015, 2019, doi: 10.11591/ijece.v9i6.pp5006-5015.

[147] I. A. Qasmieh, H. Alquran, and A. M. Alqudah, "Occluded iris classification and segmentation using self-customized artificial intelligence models and iterative randomized Hough transform," International Journal of Electrical and Computer Engineering, vol. 11, no. 5. pp. 4037-4049, 2021, doi: 10.11591/ijece.v11i5.pp4037-4049.

[148] P. N. Andono, E. H. Rachmawanto, N. S. Herman, and K. Kondo, "Orchid types classification using supervised learning algorithm based on feature and color extraction," Bulletin of Electrical Engineering and Informatics, vol. 10, no. 5. pp. 2530-2538, 2021, doi: 10.11591/eei.v10i5.3118.

[149] D. B. Setyohadi, S. Kusrohmaniah, S. B. Gunawan, Pranowo, and A. S. Prabuwono, "Galvanic skin response data classification for emotion detection," International Journal of Electrical and Computer Engineering, vol. 8, no. 5. pp. 4004-4014, 2018, doi: 10.11591/ijece.v8i5.pp4004-4014.

[150] A. E. Minarno, A. S. Maulani, A. Kurniawardhani, F. Bimantoro, and N. Suciati, "Comparison of methods for Batik classification using multi texton histogram," Telkomnika (Telecommunication Computing Electronics and Control), vol. 16, no. 3. pp. 1358-1366, 2018, doi: 10.12928/TELKOMNIKA.v16i3.7376.

[151] E. Prasetyo, R. D. Adityo, N. Suciati, and C. Fatichah, "Multi-class K-support vector nearest neighbor for mango leaf classification," Telkomnika (Telecommunication Computing Electronics and Control), vol. 16, no. 4. pp. 18261837, 2018, doi: 10.12928/TELKOMNIKA.v16i4.8482.

[152] F. M. Albkosh, M. S. Hitam, W. N. J. H. Wan Yussof, A. A. K. Abdul Hamid, and R. Ali, "Optimization of discrete wavelet transform features using artificial bee colony algorithm for texture image classification," International Journal of Electrical and Computer Engineering, vol. 9, no. 6. pp. 5253-5262, 2019, doi: 10.11591/ijece.v9i6.pp5253-5262.

[153] S. Ibrahim, N. A. Zulkifli, N. Sabri, A. A. Shari, and M. R. M. Noordin, "Rice grain classification using multi-class support vector machine (SVM)," IAES International Journal of Artificial Intelligence, vol. 8, no. 3. pp. 215-220, 2019, doi: 10.11591/ijai.v8.i3.pp215-220.

[154] A. Marathe, P. Jain, and V. Vyas, "Iterative improved learning algorithm for petrographic image classification accuracy enhancement," International Journal of Electrical and Computer Engineering, vol. 9, no. 1. pp. 289-296, 2019, doi: 10.11591/ijece.v9i1.pp.289-296. 
[155] P. X. Le and L. H. Tien, "Triple-layer remote phosphor structure: A selection of the higher color quality and lumen efficiency for wleds," Bulletin of Electrical Engineering and Informatics, vol. 10, no. 4. pp. 1960-1967, 2021, doi: 10.11591/EEI.V10I4.3084.

[156] N. T. P. Loan and A. T. Le, "Enhance the chromatic uniformity and luminous efficiency of WLEDs with triplelayer remote phosphor structures," International Journal of Electrical and Computer Engineering, vol. 10, no. 6. pp. 6244-6250, 2020, doi: 10.11591/IJECE.V10I6.PP6244-6250.

[157] H. R. Archana and K. S. Vasundara Patel, "An investigation towards effectiveness in image enhancement process in MPSoC," International Journal of Electrical and Computer Engineering, vol. 8, no. 2. pp. 963-970, 2018, doi: 10.11591/ijece.v8i2.pp963-970.

[158] R. Roslan, I. N. M. Razly, N. Sabri, and Z. Ibrahim, "Evaluation of psoriasis skin disease classification using convolutional neural network," IAES International Journal of Artificial Intelligence, vol. 9, no. 2. pp. 349-355, 2020, doi: 10.11591/ijai.v9.i2.pp349-355.

[159] M. N. Farhan, M. G. Ayoub, H. M. Qassim, and A. K. Eesee, "Qualitative assessment of image enhancement algorithms for mammograms based on minimum EDV," Telkomnika (Telecommunication Computing Electronics and Control), vol. 18, no. 2. pp. 928-935, 2020, doi: 10.12928/TELKOMNIKA.V18I2.14085.

[160] S. K. T. Hwa, A. Bade, M. H. A. Hijazi, and M. S. Jeffree, "Tuberculosis detection using deep learning and contrast-enhanced canny edge detected X-Ray images," IAES International Journal of Artificial Intelligence, vol. 9, no. 4. pp. 713-720, 2020, doi: 10.11591/ijai.v9.i4.pp713-720.

[161] A. A. Baker and Y. Ghadi, "Cancerous lung nodule detection in CT-images," Telkomnika (Telecommunication Computing Electronics and Control), vol. 18, no. 5. pp. 2432-2438, 2020, doi: 10.12928/TELKOMNIKA.v18i5.15523.

[162] S. Pearl Mary and V. Thanikaiselvan, "Unified adaptive framework for contrast enhancement of blood vessels," International Journal of Electrical and Computer Engineering, vol. 10, no. 1. pp. 767-777, 2020, doi: 10.11591/ijece.v10i1.pp767-777.

[163] T. M. Bui, P. X. Le, D. H. Bach, and N. D. Quoc Anh, "Application of triple-layer remote phosphor configuration results in the color quality and luminous efficiency enhancement of WLEDs," Telkomnika (Telecommunication Computing Electronics and Control), vol. 17, no. 6. pp. 2885-2894, 2019, doi: 10.12928/TELKOMNIKA.v17i6.13335.

[164] S. Harish and G. F. Ali Ahammed, "Integrated modelling approach for enhancing brain MRI with flexible preprocessing capability," International Journal of Electrical and Computer Engineering, vol. 9, no. 4. pp. 24162424, 2019, doi: 10.11591/ijece.v9i4.pp2416-2424.

[165] S. J. Sushma and S. C. Prasanna Kumar, "A novel approach to jointly address localization and classification of breast cancer using bio-inspired approach," International Journal of Electrical and Computer Engineering, vol. 9, no. 2. pp. 992-1001, 2019, doi: 10.11591/ijece.v9i2.pp.992-1001.

[166] K. H. Choi and S. H. Kim, "Illumination-invariant vegetation detection for a vision sensor-based agricultural applications," International Journal of Electrical and Computer Engineering, vol. 11, no. 2. pp. 1284-1292, 2021, doi: 10.11591/ijece.v11i2.pp1284-1292.

[167] S. Arifianto, H. Wibowo, W. Suharso, R. Novidianto, and D. Harmanto, "3D reconstruction using convolution smooth method," Bulletin of Electrical Engineering and Informatics, vol. 10, no. 3. pp. 1337-1344, 2021, doi: 10.11591/eei.v10i3.1991.

[168] A. M. Abadi, D. U. Wutsqa, and N. Ningsih, "Construction of fuzzy radial basis function neural network model for diagnosing prostate cancer," Telkomnika (Telecommunication Computing Electronics and Control), vol. 19, no. 4. pp. 1273-1283, 2021, doi: 10.12928/TELKOMNIKA.v19i4.20398.

[169] U. Salamah, R. Sarno, A. Z. Arifin, A. S. Nugroho, I. E. Rozi, and P. B. S. Asih, "Incorporating index of fuzziness and adaptive thresholding for image segmentation," International Journal of Electrical and Computer Engineering, vol. 8, no. 4. pp. 2406-2418, 2018, doi: 10.11591/ijece.v8i4.pp.2406-2418.

[170] D. Ongkadinata and F. P. Putri, "Quality and size assessment of quantized images using K-means++ clustering," Bulletin of Electrical Engineering and Informatics, vol. 9, no. 3. pp. 1183-1188, 2020, doi: 10.11591/eei.v9i3.1985.

[171] S. B. Jadhav, V. R. Udupi, and S. B. Patil, "Soybean leaf disease detection and severity measurement using multiclass SVM and KNN classifier," International Journal of Electrical and Computer Engineering, vol. 9, no. 5. pp. 4077-4091, 2019, doi: 10.11591/ijece.v9i5.pp4077-4091.

[172] F. M. Shamsudeen and G. Raju, "A novel equalization scheme for the selective enhancement of optical disc and cup regions and background suppression in fundus imagery," Telkomnika (Telecommunication Computing Electronics and Control), vol. 17, no. 4. pp. 1715-1722, 2019, doi: 10.12928/TELKOMNIKA.V17I4.5364.

[173] S. M. Aung, K. Kanokwiroon, T. Phairatana, and S. Chatpun, "Live and dead cells counting from microscopic trypan blue staining images using thresholding and morphological operation techniques," International Journal of Electrical and Computer Engineering, vol. 9, no. 4. pp. 2460-2468, 2019, doi: 10.11591/ijece.v9i4.pp2460-2468.

[174] W. A. Mustafa, M. M. M. A. Kader, and Z. I. A. Khalib, "Improved wolf algorithm on document images detection using optimum mean technique," Bulletin of Electrical Engineering and Informatics, vol. 8, no. 2. pp. 551-557, 2019, doi: 10.11591/eei.v8i2.1426.

[175] R. N. Rohmah, B. Handaga, Nurokhim, and I. Soesanti, "A statistical approach on pulmonary tuberculosis detection system based on X-ray image," Telkomnika (Telecommunication Computing Electronics and Control), vol. 17, no. 3. pp. 1474-1482, 2019, doi: 10.12928/TELKOMNIKA.v17i3.10546.

[176] J. Naàm, J. Harlan, S. Madenda, J. Santony, and C. Suharinto, "Detection of proximal caries at the molar teeth using edge enhancement algorithm," International Journal of Electrical and Computer Engineering, vol. 8, no. 5. pp. 3259-3266, 2018, doi: 10.11591/ijece.v8i5.pp.3259-3266. 
[177] R. Kurniawan, A. Kurniawardhani, and I. Muhimmah, "Inflammatory cell extraction in pap smear images: A combination of distance criterion and image transformation approach," Telkomnika (Telecommunication Computing Electronics and Control), vol. 16, no. 5. pp. 2048-2056, 2018, doi: 10.12928/TELKOMNIKA.v16i5.6817.

[178] Y. A. Fadil, B. Al-Bander, and H. Y. Radhi, "Enhancement of medical images using fuzzy logic," Indonesian Journal of Electrical Engineering and Computer Science, vol. 23, no. 3. pp. 1478-1484, 2021, doi: 10.11591/ijeecs.v23.i3.pp1478-1484.

[179] M. A. K. Azad, A. Majumder, J. K. Das, and M. I. Islam, "Improving signal detection accuracy at FC of a CRN using machine learning and fuzzy rules," Indonesian Journal of Electrical Engineering and Computer Science, vol. 21, no. 2. pp. 1140-1150, 2020, doi: 10.11591/ijeecs.v21.i2.pp1140-1150.

[180] A. S. A. Salam, M. N. B. M. Isa, and M. I. Ahmad, "Spatial domain image enhancement techniques for acute myeloid leukemia (M1,M4,M5,M7)," Indonesian Journal of Electrical Engineering and Computer Science, vol. 14, no. 1. pp. 250-257, 2019, doi: 10.11591/ijeecs.v14.i1.pp250-257.

[181] S. Nazeeburrehman and M. A. Hussain, "Image resolution enhancement using transform," Indonesian Journal of Electrical Engineering and Computer Science, vol. 9, no. 2. pp. 354-356, 2018, doi: 10.11591/ijeecs.v9.i2.pp354-356.

[182] M. A. El-Wahed, B. Zoheir, A. B. Pour, and S. Kamh, "Shear-related gold ores in the wadi hodein shear belt, south eastern desert of egypt: Analysis of remote sensing, field and structural data," Minerals, vol. 11, no. 5. 2021, doi: $10.3390 / \min 11050474$.

[183] S. Rajendran et al., "WorldView-3 mapping of Tarmat deposits of the Ras Rakan Island, Northern Coast of Qatar: Environmental perspective," Marine Pollution Bulletin, vol. 163. 2021, doi: 10.1016/j.marpolbul.2021.111988.

[184] I. A. Dar, K. Sankar, and M. A. Dar, "Remote sensing technology and geographic information system modeling: An integrated approach towards the mapping of groundwater potential zones in Hardrock terrain, Mamundiyar basin," Journal of Hydrology, vol. 394, no. 3-4. pp. 285-295, 2010, doi: 10.1016/j.jhydrol.2010.08.022.

[185] S. Scheidt, M. Ramsey, and N. Lancaster, "Radiometric normalization and image mosaic generation of ASTER thermal infrared data: An application to extensive sand sheets and dune fields," Remote Sensing of Environment, vol. 112, no. 3. pp. 920-933, 2008, doi: 10.1016/j.rse.2007.06.020.

[186] J. P. Matthews and A. S. G. Jones, "Mapping the Xigaze (Tibet) ophiolite complex with Landsat Thematic Mapper data," Journal of Himalayan Geology, vol. 3, no. 1. pp. 97-101, 1992.

[187] S. Rajendran et al., "Sentinel-2 image transformation methods for mapping oil spill - A case study with Wakashio oil spill in the Indian Ocean, off Mauritius," MethodsX, vol. 8. 2021, doi: 10.1016/j.mex.2021.101327.

[188] S. Rajendran and S. Nasir, "ASTER mapping of gypsum deposits of Thumrait region of southern Oman," Resource Geology, vol. 71, no. 1. pp. 41-62, 2021, doi: 10.1111/rge.12245.

[189] E. Pastucha, E. Puniach, A. Ścisłowicz, P. Ćwiakąła, W. Niewiem, and P. Wiącek, "3D reconstruction of power lines using uav images to monitor corridor clearance," Remote Sensing, vol. 12, no. 22. pp. 1-31, 2020, doi: $10.3390 /$ rs 12223698 .

[190] M. W. Ali-Bik, S. M. Hassan, M. A. Abou El Maaty, S. H. Abd El Rahim, S. D. Abayazeed, and W. A. Wahab, "The late Neoproterozoic Pan-African low-grade metamorphic ophiolitic and island-arc assemblages at Gebel Zabara area, Central Eastern Desert, Egypt: Petrogenesis and remote sensing - Based geologic mapping," Journal of African Earth Sciences, vol. 144. pp. 17-40, 2018, doi: 10.1016/j.jafrearsci.2018.04.001.

[191] F. Gnädinger and U. Schmidhalter, "Digital counts of maize plants by Unmanned Aerial Vehicles (UAVs)," Remote Sensing, vol. 9, no. 6. 2017, doi: 10.3390/rs9060544.

[192] A. Shukla and B. Yousuf, "Evaluation of multisource data for glacier terrain mapping: a neural net approach," Geocarto International, vol. 32, no. 5. pp. 569-587, 2017, doi: 10.1080/10106049.2016.1161078.

[193] G. C. Miliaresis, "Iterative selective spatial variance reduction of MYD11A2 LST data," Earth Science Informatics, vol. 10, no. 1. pp. 15-27, 2017, doi: 10.1007/s12145-016-0271-5.

[194] N. S. Öztan and M. L. Süzen, "Mapping evaporate minerals by ASTER,” International Journal of Remote Sensing, vol. 32, no. 6. pp. 1651-1673, 2011, doi: 10.1080/01431160903586799.

[195] M. Lakshminarayana and M. Sarvagya, "MICCS: A novel framework for medical image compression using compressive sensing," International Journal of Electrical and Computer Engineering, vol. 8, no. 5. pp. 2818-2828, 2018, doi: 10.11591/IJECE.V8I5.PP2818-2828.

[196] S. M. Vijaya and K. Suresh, "An efficient design approach of ROI based DWT using vedic and wallace tree multiplier on FPGA platform," International Journal of Electrical and Computer Engineering, vol. 9, no. 4. pp. 2433-2442, 2019, doi: 10.11591/ijece.v9i4.pp2433-2442.

[197] M. J. Fadhil, R. A. Fayadh, and M. K. Wali, "Design and implementation a prototype system for fusion image by using SWT-PCA algorithm with FPGA technique," International Journal of Electrical and Computer Engineering, vol. 10, no. 1. pp. 757-766, 2020, doi: 10.11591/ijece.v10i1.pp757-766.

[198] A. Singh and J. Singh, "Content adaptive single image interpolation based Super Resolution of compressed images," International Journal of Electrical and Computer Engineering, vol. 10, no. 3. pp. 3014-3021, 2020, doi: 10.11591/ijece.v10i3.pp3014-3021.

[199] D. Monica and A. Widipaminto, "Fuzzy transform for high-resolution satellite images compression," Telkomnika (Telecommunication Computing Electronics and Control), vol. 18, no. 2. pp. 1130-1136, 2020, doi: 10.12928/TELKOMNIKA.v18i2.14903. 